\title{
Assessment of Growth and Technological Performances of Yogurt Bacteria Isolated From Local Turkish Yogurts
}

\author{
Irem Uzunsoy ${ }^{1}$, Sebnem Ozturkoglu Budak ${ }^{2}$, Tuba Sanli $^{2},{\text { Birce } \operatorname{Taban}^{2}}^{\circledR},{\text { Aykut } \text { Aytac }^{3}}^{\circledR}$, Nuray \\ Yazihan $^{4,5}$, Barbaros Ozer ${ }^{2 *}$ \\ ${ }^{1}$ Bulent Ecevit University Caycuma Vocational School, Caycuma, Zonguldak, Turkey \\ ${ }^{2}$ Department of Dairy Technology, Faculty of Agriculture, Ankara University, Diskapi, Ankara, Turkey \\ ${ }^{3}$ Department of Food Engineering, Faculty of Engineering, Hacettepe University, Beytepe, Ankara, Turkey \\ ${ }^{4}$ Department of Pathophysiology, Faculty of Medicine, Ankara University, Sihhiye, Ankara, Turkey \\ ${ }^{5}$ Department of Food, Metabolism and Clinical Nutrition, Institute of Health Sciences, Ankara University, Sihhiye, Ankara, Turkey \\ E-mail: adabarbaros@gmail.com
}

Received: 24 December 2020; Revised: 12 April 2021; Accepted: 28 April 2021

\begin{abstract}
Growth patterns and some technological performances of five Streptococcus thermophilus and seven Lactobacillus delbrueckii subsp. bulgaricus strains isolated from yogurt samples which were collected from remote rural areas of Anatolia, Turkey were assessed. The single isolates were screened for milk acidification performances, production of volatile organic compounds and texture developing properties, and selected isolates were combined to use in yogurt-making. Yogurt samples were subjected to sensory evaluations as well as fermentation profiles. Finally, the combinations of one Streptococcus thermophilus isolate with all Lactobacillus delbrueckii subsp. bulgaricus strains were found to have potentials for further evaluations regarding their suitability for commercial applications.
\end{abstract}

Keywords: yogurt, starter, flavor, texture

\section{Introduction}

Yogurt is perhaps one of the oldest fermented foods and is believed to be spread from Central Asia to the rest of the World via migration routes of nomadic people [1]. Although the health benefits of yogurt dates back to $6000 \mathrm{BC}$ in Ayurvedic Indian scripts, its scientific demonstration was rather new. In the early $20^{\text {th }}$ century, Lactobacillus delbrueckii subsp. bulgaricus (formerly named Bacillus bulgaricus) was isolated from yogurt and associated with longevity in the Bulgarian peasant people [2]. Current standard procedures and regulations call for the addition of Streptococcus thermophilus (Str. thermophilus) and Lactobacillus delbrueckii subsp. bulgaricus (Lb. bulgaricus) in the manufacture of yogurt [3,4]. The textural and organoleptic properties of yogurt are largely determined by the strains of these two species. The harmony between two or more strains of these species is essential for development of a well-balanced aroma/flavor and texture in yogurt. For this reason, many studies have been dedicated to screen the strains of these two yogurt bacteria for their suitability for commercial applications $[5,6]$. Very few number of screened strains have reached a commercial success since these strains have to meet basic selection criteria for being used as starter culture in yogurt-making. These criteria include safety for human consumption, acidification rate of milk, aroma producing and

Copyright (C2021 Barbaros Ozer, et al.

DOI: https://doi.org/10.37256/fse.222021758

This is an open-access article distributed under a CC BY license

(Creative Commons Attribution 4.0 International License)

https://creativecommons.org/licenses/by/4.0/ 
texture promoting capacities, growth kinetics, bacteriophage resistance, sustainable production at commercial level, i.e., reproducibility and suitability for freeze-drying and so on $[5,7]$. Today, many of these traits of yogurt bacteria may well be improved using modern molecular techniques $[8,9]$.

In yogurt production, back-slopping fermentation model has been largely replaced by commercial culture-based fermentation model in many countries. This shift has eventually caused a progressive loss of microbial diversity and characteristic sensory properties of traditional yogurt. The consumers' expectations from yogurt have changed in recent years. Standard consumers demand more natural yogurt with taste and textural properties that they are used to. In order to meet consumers' demand towards local tastes and textures in yogurt, a re-designing of yogurt production has become a necessity for yogurt industry. Therefore, efforts have been accelerated to find out the novel yogurt starter strains from the local diversity of lactic acid bacteria [6, 10-12]. The common screening protocol for wild type Str. thermophilus and $\mathrm{Lb}$. bulgaricus strains follow isolation of colonies using a suitable culturing medium (M17 agar for the former and MRS agar for the latter species), and phenotypic (i.e., morphological examination, growing at different temperatures, Gram-staining, sugar fermentation, salt and acid resistance) and genotypic (Real Time-PCR, MALDI-TOF, DGGE, PFGE, ribotyping, fluorescent in situ hybridization, 16S rRNA sequencing, metagenomics analysis etc.) identification of the colonies [13]. Today, genotypic identification of lactic acid bacteria is achieved with high sensitivity by using one or more of the techniques mentioned above. However, most difficult part of culture development studies is to find the best combination of Str. thermophilus and Lb. bulgaricus strains to obtain yogurt with a balanced taste/aroma and texture. To do so, all isolated and identified strains should be subjected to technological performance tests and culture combinations should be prepared based on the results of these pre-selection tests. These combinations are further used in the manufacture of yogurt with desired characteristics.

Present study aimed at screening the isolates of Str. thermophilus and Lb. bulgaricus which were previously isolated from local fermented dairy products in Anatolia, Turkey for their growth patterns, technological performances and suitability for yogurt-making.

\section{Materials and methods}

\subsection{Bacterial strains and chemicals}

Table 1. Characteristics of the isolates from traditional yogurt samples in Anatolia, Turkey

\begin{tabular}{|c|c|c|c|c|c|}
\hline & Isolate no & Strains & 16S rRNA Gene Bank & Dairy product & Isolation location \\
\hline \multirow{5}{*}{ Str. thermophilus } & ST1 & MGB80-7 & НМ058270.1 & Yogurt & Bolu \\
\hline & ST2 & PON458 & KC545934.1 & Yogurt & Ermenek \\
\hline & ST3 & IMAU11370 & КР764074.1 & Yogurt & Bolu \\
\hline & ST4 & S9 & СР013939.1 & Yogurt & Ermenek \\
\hline & ST5 & KLDS SM & СР016026.1 & Yogurt & Ermenek \\
\hline \multirow{7}{*}{ Lb. bulgaricus } & LB1 & SB25 & KJ868760 & Yogurt & Ermenek \\
\hline & LB2 & MGB27-2 & HM058081.1 & Yogurt & Sertavul \\
\hline & LB3 & IMAU11365 & KР764119.1 & Yogurt & Mut \\
\hline & LB4 & NWAFU1436 & MG551099.1 & Yogurt & Mut \\
\hline & LB5 & SKB1083 & MK564723.1 & Yogurt & Merzifon \\
\hline & LB6 & MN-BM-F01 & СР013610.1 & Yogurt & Merzifon \\
\hline & LB7 & JCM 1002 & LC063162.1 & Yogurt & Merzifon \\
\hline
\end{tabular}

Bacterial strains were obtained from culture collection formed within the scope of a project entitled "Development 
of Industrial Yogurt Starter Combinations Using Local Sources" (Project No: 112D052, financially supported by The Scientific and Technological Research Council of Turkey-TUBITAK). The characteristics of the strains are given in Table 1. The strains used in this study were obtained from traditional yogurt samples collected from different rural areas of Anatolia, Turkey. In total, 5 Str. thermophilus and $7 \mathrm{Lb}$. bulgaricus strains were screened for their growth properties and technological performances. All chemicals were supplied from Sigma-Aldrich Inc. (Sigma-Aldrich Inc., St. Louis, MO, USA) unless otherwise stated. Skimmed milk powder and cow's milk were supplied from Ankara University Dairy Farm and yogurt productions were carried out at Ankara University Department of Dairy Technology Pilot Dairy Plant.

\subsection{Activation of the strains and preparation of working cultures for yogurt production}

Activation of the strains was achieved by adding $20 \mu \mathrm{l}$ of Lb. bulgaricus and Str. thermophilus strains into 5 $\mathrm{ml}$ of MRS and M17 broths, respectively. While the tubes containing Lb. bulgaricus strains were incubated at $43^{\circ} \mathrm{C}$ for $72 \mathrm{~h}$ under anaerobic conditions, tubes containing the strains of Str. thermophilus were incubated at $37^{\circ} \mathrm{C}$ for $24 \mathrm{~h}$ aerobically. $0.5 \mathrm{ml}$ of pre-activated strains were inoculated into $50 \mathrm{ml}$ of sterile reconstituted milk $(10 \%$, w/v) to obtain a working culture for yogurt-making. Reconstituted milk was incubated at $43^{\circ} \mathrm{C}$ until gelation was complete and the working cultures were kept at $4^{\circ} \mathrm{C}$ for $24 \mathrm{~h}$ before use. Yogurt samples were prepared by inoculating $100 \mathrm{ml}$ of heattreated $\left(\right.$ at $90^{\circ} \mathrm{C}$ for $\left.10 \mathrm{~min}\right)$ fresh cow's milk $[3.2 \%(\mathrm{w} / \mathrm{v})$ milk fat and $3.0 \%(\mathrm{w} / \mathrm{v})$ protein] with working culture $(2 \%$, $\mathrm{w} / \mathrm{v})$. Combined cultures were prepared by mixing single isolates of Str. thermophilus and Lb. bulgaricus at 1 to 1 ratio. Samples were incubated at $43^{\circ} \mathrm{C}$ until $\mathrm{pH} 4.6$ was attained. Then the fermented milks were kept at $4^{\circ} \mathrm{C}$ for 14 days. The preparation of working cultures and yogurt samples is summarized in Figure 1.



Figure 1. Schematic illustration of preparation of working culture and experimental yogurts. For incubation conditions refer to text

\subsection{Determination of specific growth rates and growth patterns of the strains}

Maximal growth rates of the strains were determined by measuring optical density of the growth mediums at $600 \mathrm{~nm}\left(\mathrm{OD}_{600}\right)$ at the beginning and end of $24 \mathrm{~h}$ growth period [14]. Twenty microliters of each activated strains were transferred into a suitable broth medium and incubated at $43^{\circ} \mathrm{C}$ anaerobically for $\mathrm{Lb}$. bulgaricus and at $37^{\circ} \mathrm{C}$ aerobically for Str. thermophilus. OD $_{600}$ values were measured using a UV/VIS spectrophotometer (Perkin Elmer Inc., Massachussetts, USA). When necessary, broths containing single strains were diluted with sterile pure water and in the calculation of maximal growth rate, the dilution rate was considered. Maximal growth rate $\left(\mu_{\max }\right)$ of each strain was calculated using the following formula: 
Maximal growth rate $\left(\mu_{\max }\right)=2.303 \times\left(\mathrm{OD}_{600124}-\mathrm{OD}_{600 ~ t 0}\right) / 24$

Growth patterns of the isolates were determined by measuring $\mathrm{OD}_{600}$ values throughout $24 \mathrm{~h}$ incubation with $3 \mathrm{~h}$ intervals. In order to avoid the erroneous results, culture conditions (batch and volume of growth medium, size of culture vessel and incubation conditions etc.) were kept same.

\subsection{Textural properties of yogurt samples made by single strains}

Large deformation textural characteristics of yogurt samples produced by single strains were determined by means of a Texture Profile Analyzer (model TX.2TA, Stable Micro Systems, Godalming, UK) using back extrusion mode. The measuring conditions were as follows: cell load, $5 \mathrm{~kg}$; cylindrical probe with $20 \mathrm{~mm}$ diameter; penetration depth of probe $15 \mathrm{~mm}$ and penetration speed, $1 \mathrm{~mm} / \mathrm{s}$. Measurements were achieved at $4^{\circ} \mathrm{C}$. Three measurements were done for each sample.

\subsection{Determination of volatile aroma compounds of single strain yogurts}

Aroma profiles of the yogurt samples produced by single isolates were determined using a Gas Chromatography/ Mass (GC/MS) system (Agilent 7890A GC-5975 MSD, Agilent Technologies, CA, USA). The volatiles were extracted using divinylbenzene/carboxen/polydimethylsiloxane (DVB/CAR/PDMS) fiber [15]. Five grams of yogurt sample were mixed with $10 \mu \mathrm{l}$ of internal standards (2-methyl-3-heptanon and 2-methyl pentanoic acid in $81 \mathrm{mg} / \mathrm{kg}$ methanol) and the mixture was stirred at $50^{\circ} \mathrm{C}$ for $30 \mathrm{~min}$. The volatile compounds were separated using a DB-Wax column $(30 \mathrm{~m}, 0.25$ $\mathrm{mm}, 0.25 \mu \mathrm{m}$; J\&W Scientific, Folsom, CA, USA). Helium was used as the carrier gas ( $1 \mathrm{ml} / \mathrm{min})$. The oven was held at $40^{\circ} \mathrm{C}$ for $10 \mathrm{~min}$ (desorption period), then increased $5^{\circ} \mathrm{C}$ per min to $110^{\circ} \mathrm{C}$. The temperature was then raised by $10^{\circ} \mathrm{C}$ per $\min$ to $240^{\circ} \mathrm{C}$ to give a run time of $15 \mathrm{~min}$. The mass spectrometer was set to record at $35-500 \mathrm{~m} / \mathrm{z}$ (threshold 150) at a sampling rate of $5.19 \mathrm{scan} / \mathrm{s}$. The quantification of the volatiles was achieved by comparing the peak area of each volatile compound with peak area of internal standard using the following formula and the results were expressed as proportional amount $(\mathrm{mg} / \mathrm{kg})$ :

Volatile compounds $=81 \times$ peak area of volatile compound $/$ peak area of internal standard

\subsection{Descriptive sensory analysis of yogurt samples}

Yogurt samples produced by combined yogurt cultures were subjected to descriptive sensory analysis using Spectrum $^{\mathrm{TM}}$ Descriptive Analysis Method as described in Meilgaard et al. [16]. Panel group consisted of five persons who were trained previously on sensory evaluation of fermented dairy products including basic taste, texture and flavor identification. Each sensory trait was converted to metric values using Spectrum Universal intensity scale. In this spectrum, " 0 " represented the unidentified sensory trait and " 15 " represented the strongest sensory trait. Samples (100 ml) were served to the panelists in cups bearing a random 3-digit number at $10^{\circ} \mathrm{C}$ and maximum six yogurt samples were evaluated by the panel group at one session. Panelists were provided with bread stick and a glass of water between each sample.

\subsection{Statistical analysis}

Data were statistically processed with one-way analysis of variance (ANOVA) using the SPSS Software (SPSS ver. 17, SPSS Inc., Chicago, IL, USA). Differences between groups were determined by Least Significant Difference (LSD) test $(\mathrm{p}<0.05)$. The experiment was repeated three times $(\mathrm{n}=3)$.

\section{Results and discussion}

\subsection{Maximal growth rates and growth patterns of single strains}

Maximal growth rates $\left(\mu_{\max }\right)$ and growth profiles of single strains are given in Table 2, and Figures 2 and 3, 
respectively. Overall, the maximal growth rates of Str. thermophilus strains were much higher than Lb. bulgaricus strains. The highest maximal growth rates were found in the isolates ST3, ST4 and ST2, in decreasing order. While the maximal growth rates of Str. thermophilus strains ranged between 0.0736 and $0.22041 / \mathrm{h}$, these figures were between 0.0032 and 0.0379 1/h in the Lb. bulgaricus strains. As seen in Figures 2 and 3, all Str. thermophilus strains reached the stationary phase of growth within 9-12 hours of incubation. Isolate ST1 showed rather an atypical growth pattern for Str. thermophilus and had a shorter lag phase than the rest of the Str. thermophilus strains. All Lb. bulgaricus strains had far longer lag phases of growth than Str. thermophilus isolates. Lb. bulgaricus strains had similar growth patterns with varying $\mathrm{OD}_{600}$ values. Proto-cooperation between yogurt bacteria has long been known. Both yogurt bacteria stimulates the growth of each other by providing essential growth promoters which are needed by its partner organism for the growth [17]. The protocooperation between yogurt bacteria is not only on nutritional exchanges, but also dramatic physiological changes in these two bacteria are evident [18]. In mixed cultures, Str. thermophilus shows rather lower resistance to acidity than $\mathrm{Lb}$. bulgaricus and hence, reaches to stationary phase earlier than its counterpart. The growth of Str. thermophilus slows down, to a great extent, at $\mathrm{pH}$ 4.2-4.4. On the contrary, Lb. bulgaricus is able to tolerate lower $\mathrm{pH}$ values, i.e. $\mathrm{pH}$ 3.5-3.8 [19].

Table 2. Maximal growth rates $\left(\mu_{\max }, 1 / \mathrm{h}\right)$ of the isolates $(\mathrm{n}=3)$

\begin{tabular}{cc}
\hline & Str. thermophilus \\
ST1 & $0.0736 \pm 0.0038^{\mathrm{a}}$ \\
ST2 & $0.1405 \pm 0.0195^{\mathrm{b}}$ \\
ST3 & $0.2204 \pm 0.0760^{\mathrm{c}}$ \\
ST4 & $0.1669 \pm 0.0176^{\mathrm{d}}$ \\
ST5 & $0.1000 \pm 0.0080^{\mathrm{e}}$ \\
\hline & Lb. bulgaricus \\
LB1 & $0.0032 \pm 0.0002^{\mathrm{f}}$ \\
LB2 & $0.0323 \pm 0.0005^{\mathrm{g}}$ \\
LB3 & $0.0379 \pm 0.0010^{\mathrm{h}}$ \\
LB4 & $0.0256 \pm 0.0010^{\mathrm{i}}$ \\
LB5 & $0.0137 \pm 0.0010^{\mathrm{j}}$ \\
LB6 & $0.0228 \pm 0.0001^{\mathrm{k}}$ \\
LB7 & $0.0148 \pm 0.0002^{1}$ \\
\hline
\end{tabular}

*Different superscript letters indicate statistically different groups $(\mathrm{p}>0.05)$

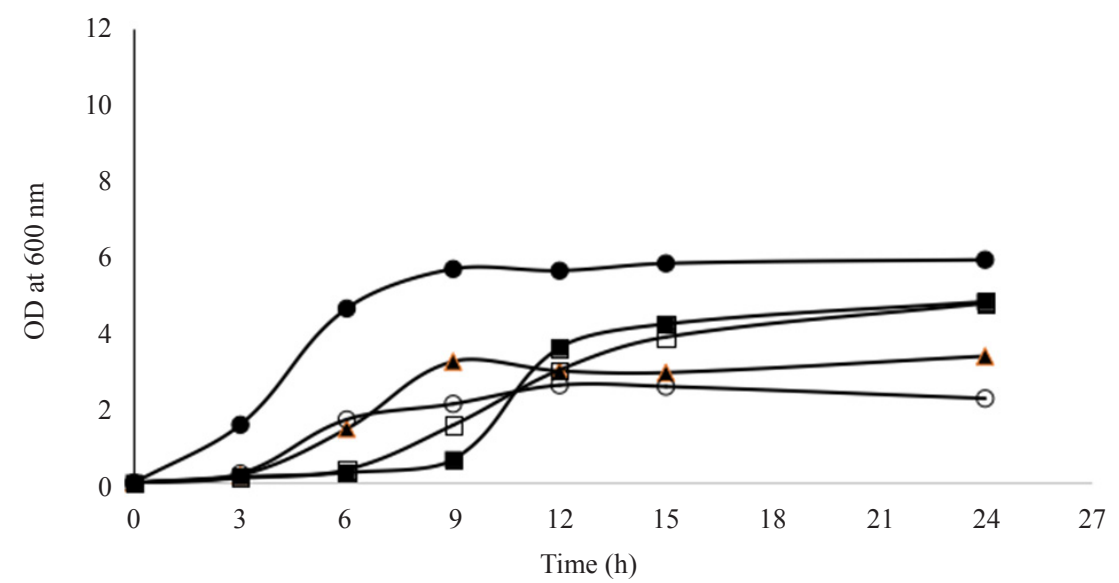

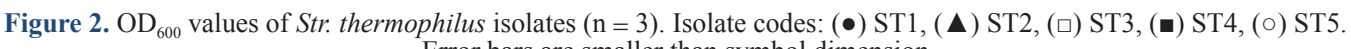
Error bars are smaller than symbol dimension 


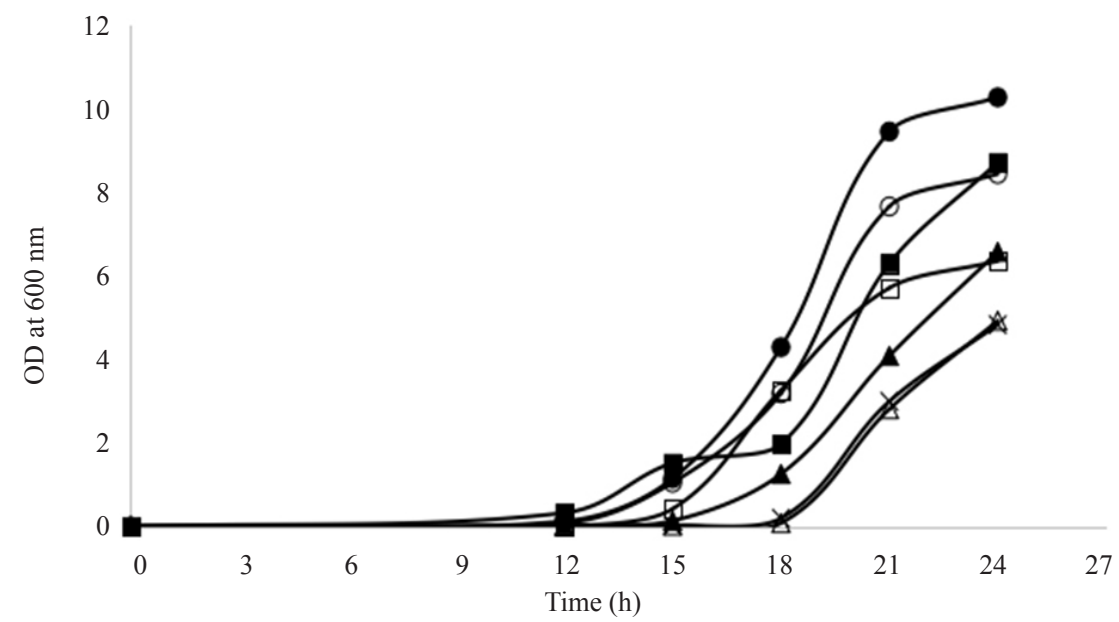

Figure 3. $\mathrm{OD}_{600}$ values of Lb. bulgaricus isolates $(\mathrm{n}=3)$. Isolate codes: $(\bullet) \mathrm{LB} 1,(\circ) \mathrm{LB} 2,(\square) \mathrm{LB} 3,(\boldsymbol{\bullet}) \mathrm{LB} 4,(\times) \mathrm{LB} 5,(\Delta) \mathrm{LB} 6,(\boldsymbol{\Delta}) \mathrm{LB} 7$. Error bars are smaller than symbol dimension

\subsection{Acidification profiles of yogurts}

Acidification profiles of working cultures and yogurts made by single strains are given in Table 3. Among Str. thermophilus strains, the fastest gel formation of working cultures was observed in the ones inoculated with isolates ST3 and ST4 (gel formation time of working culture between 400-490 min). ST2 was the slowest acid-producing isolate with 960 min of gelation time. Lb. bulgaricus strains were rather slower acid-producers compared to Str. thermophilus strains. The average gelation time of the working cultures inoculated with Lb. bulgaricus strains were between 690 min and $1580 \mathrm{~min}$. Working cultures were used in the manufacture of experimental yogurt samples at a level of $2 \%$ (w/v). Inoculated milks were incubated at $43^{\circ} \mathrm{C}$ until $\mathrm{pH} 4.7$ was attained. The isolates ST4 and ST5 acidified the milk faster (within $235 \mathrm{~min}$ and $280 \mathrm{~min}$, respectively) than the rest of the Str. thermophilus isolates. Among Lb. bulgaricus isolates, LB2 and LB4 were the fastest acid-producers (reaching pH 4.6-4.7 within 270-290 min). The decrease in $\mathrm{pH}$ of yogurt samples continued during $24 \mathrm{~h}$-refrigeration, being more pronounced in the samples inoculated with isolates ST1 and ST5 in the Str. thermophilus group and LB1, LB2 and LB4 in the Lb. bulgaricus group.

\subsection{Textural properties of yogurt samples}

Viscosity index and firmness values of 1-day old yogurt samples are presented in Figures 4 and 5, respectively. Among Str. thermophilus isolates, ST5 yielded the firmest yogurt with $484.98 \mathrm{~g}$. Overall, except for the isolates LB2 and LB4, Lb. bulgaricus strains tested led to yogurt samples with lower firmness values than that made by Str. thermophilus strains. Firmness is defined as the maximum peak force during the first compression cycle and is required to create a certain degree of deformation in the product. Firmness is an important textural parameter for assessing the physical quality of yogurt [20]. The strength of the internal bonds making up yogurt body was the highest in the samples made by single isolates of ST5 and LB2 as evidenced by high cohesiveness values in these samples (not shown). The lowest consistency values were obtained in yogurts made by single isolates of LB5, LB6 and LB7. Consistency and viscosity index are related textural parameters; consistency indicates the thickness of the body of yogurt and viscosity index gauges the resistance of the sample to flow off the disc during back extrusion [21]. Yogurt samples made by isolate ST5 in the Str. thermophilus group and LB2 and LB3 in the Lb. bulgaricus group had the highest viscosity index values. The isolates ST5 and LB2 positively differ from the rest of the isolates in terms of their contributions to the textural properties of yogurt matrix. 
Table 3. Acidification capacities of the strains $(n=3)$

\begin{tabular}{|c|c|c|c|c|}
\hline Isolates & $\begin{array}{l}\text { Time to set for working cultures } \\
\text { (min) }\end{array}$ & $\begin{array}{l}\text { Incubation time of yogurt } \\
\text { (min) }\end{array}$ & $\begin{array}{l}\mathrm{pH} \text { of yogurt at the end of } \\
\text { incubation period }\end{array}$ & $\begin{array}{c}\mathrm{pH} \text { of yogurt after } \\
\text { overnight refrigeration }\end{array}$ \\
\hline \multicolumn{5}{|c|}{ Str. thermophilus } \\
\hline ST1 & $680 \pm 14.0^{\mathrm{a}}$ & $470 \pm 45.0^{\mathrm{a}}$ & $4.67 \pm 0.018^{\mathrm{aA}}$ & $4.52 \pm 0.011^{\mathrm{acB}}$ \\
\hline ST2 & $960 \pm 11.0^{\mathrm{b}}$ & $660 \pm 9.00^{\mathrm{b}}$ & $4.68 \pm 0.029^{\mathrm{aA}}$ & $4.67 \pm 0.044^{\mathrm{bA}}$ \\
\hline ST3 & $490 \pm 14.0^{c}$ & $435 \pm 30.0^{\mathrm{a}}$ & $4.66 \pm 0.033^{\mathrm{aA}}$ & $4.61 \pm 0.060^{\mathrm{bB}}$ \\
\hline ST4 & $400 \pm 31.0^{\mathrm{d}}$ & $235 \pm 4.00^{c}$ & $4.53 \pm 0.011^{\mathrm{bA}}$ & $4.52 \pm 0.023^{\mathrm{acA}}$ \\
\hline ST5 & $660 \pm 16.0^{\mathrm{a}}$ & $280 \pm 7.00^{\mathrm{d}}$ & $4.69 \pm 0.013^{\mathrm{aA}}$ & $4.56 \pm 0.019^{\mathrm{aB}}$ \\
\hline \multicolumn{5}{|c|}{ Lb. bulgaricus } \\
\hline LB1 & $960 \pm 16.0^{b}$ & $805 \pm 22.0^{\mathrm{e}}$ & $4.70 \pm 0.055^{\text {adA }}$ & $4.56 \pm 0.011^{\mathrm{aB}}$ \\
\hline LB2 & $690 \pm 45.0^{\mathrm{a}}$ & $290 \pm 10.0^{\mathrm{f}}$ & $4.64 \pm 0.064^{\mathrm{aA}}$ & $4.51 \pm 0.018^{\mathrm{cB}}$ \\
\hline LB3 & $1.440 \pm 35.0^{\mathrm{e}}$ & $715 \pm 33.0^{\mathrm{g}}$ & $4.65 \pm 0.055^{\mathrm{aA}}$ & $4.64 \pm 0.029^{\mathrm{bA}}$ \\
\hline LB4 & $810 \pm 44.0^{\mathrm{f}}$ & $270 \pm 55.0^{\mathrm{f}}$ & $4.43 \pm 0.028^{\mathrm{cA}}$ & $4.33 \pm 0.008^{\mathrm{dB}}$ \\
\hline LB5 & $1.580 \pm 29.0^{\mathrm{g}}$ & $672 \pm 14.0^{\mathrm{b}}$ & $4.68 \pm 0.038^{\mathrm{aA}}$ & $4.67 \pm 0.010^{\mathrm{bA}}$ \\
\hline LB6 & $741 \pm 10.0^{\mathrm{h}}$ & $827 \pm 15.0^{\mathrm{e}}$ & $4.70 \pm 0.024^{\mathrm{adA}}$ & $4.70 \pm 0.019^{\mathrm{bA}}$ \\
\hline LB7 & $1.578 \pm 8.00^{\mathrm{g}}$ & $677 \pm 38.0^{\text {bg }}$ & $4.72 \pm 0.005^{\mathrm{dA}}$ & $4.69 \pm 0.066^{\mathrm{bA}}$ \\
\hline
\end{tabular}

*Different lower case superscript letters in the same columns and upper case superscript letters in the same line indicate statistically different groups $(\mathrm{p}<0.05)$

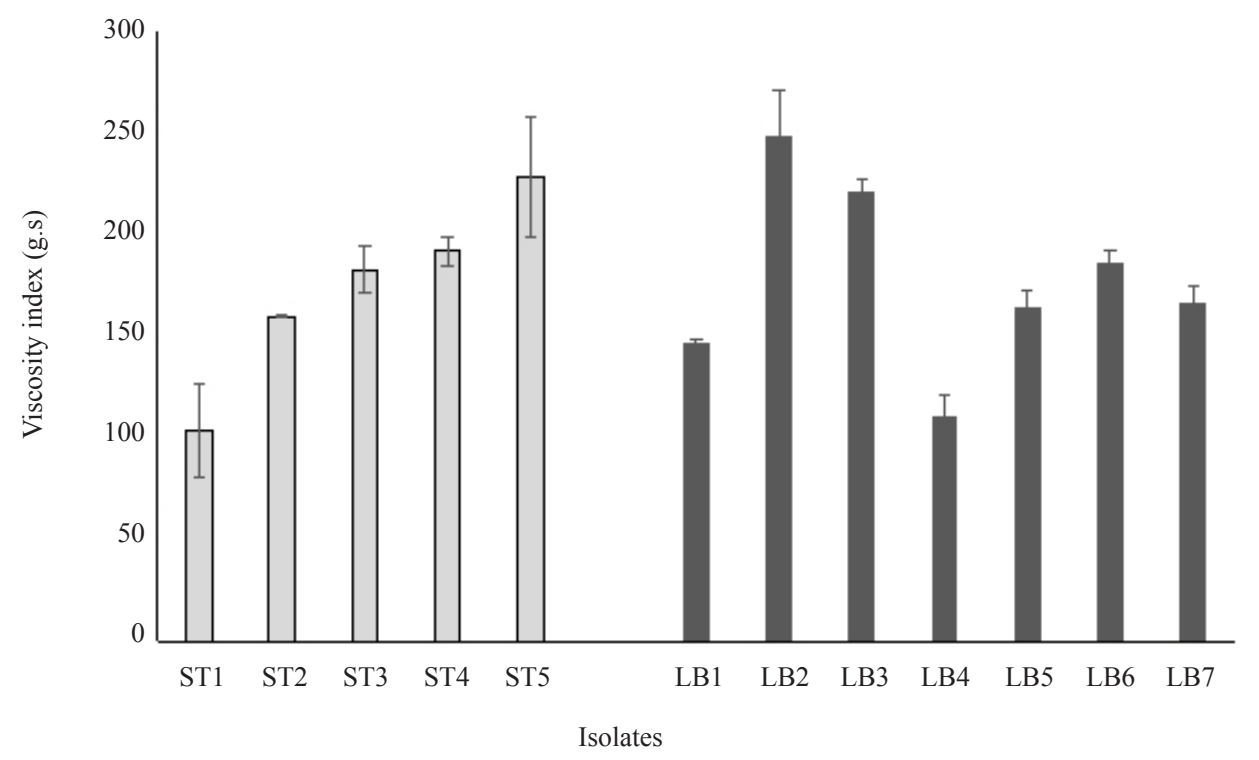

Figure 4. Viscosity index values of the yogurt samples made by single cultures of Str. thermophilus or Lb. bulgaricus ( $\mathrm{n}=3$ ) 


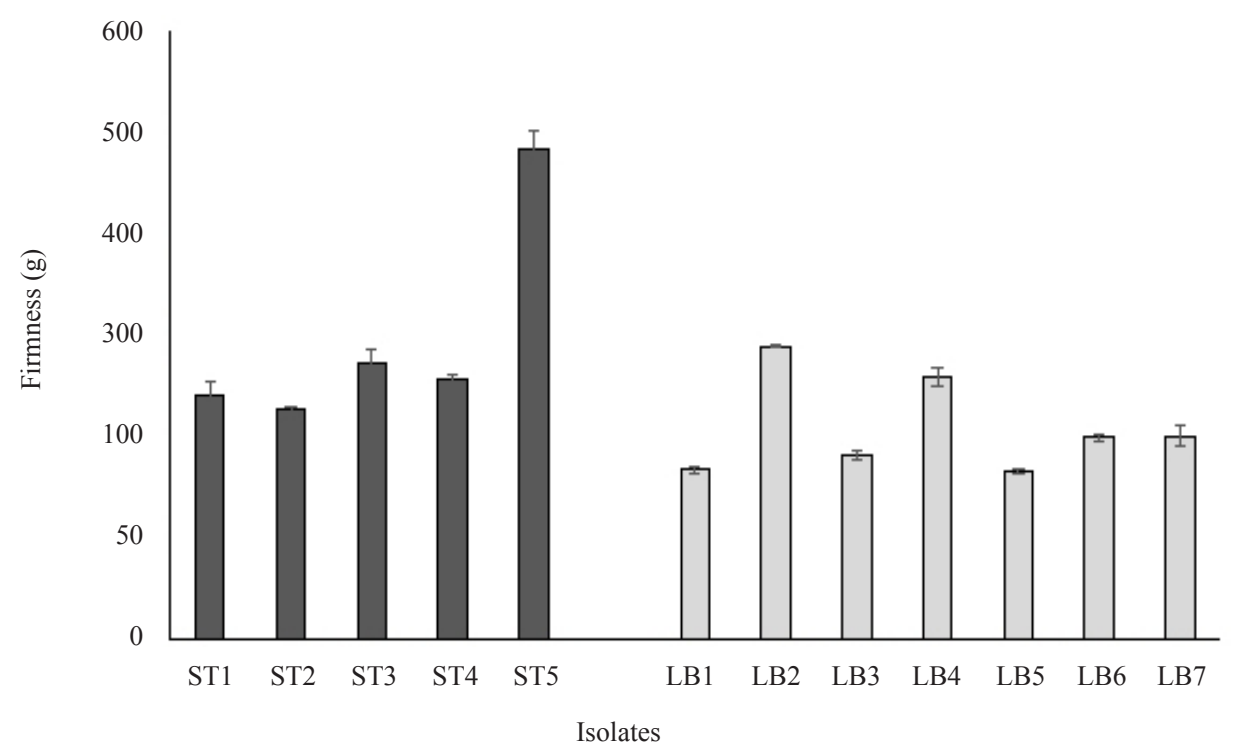

Figure 5. Firmness values of the yogurt samples made by single cultures of Str. thermophilus or Lb. bulgaricus $(\mathrm{n}=3)$

Table 4. Major aroma compounds of yogurts made by single strains of Str. thermophilus or Lb. bulgaricus $(\mathrm{mg} / \mathrm{kg})(\mathrm{n}=3)$

\begin{tabular}{|c|c|c|c|c|c|c|c|c|c|c|c|c|}
\hline \multirow{2}{*}{ Compounds } & \multicolumn{12}{|c|}{ Isolates } \\
\hline & ST1 & ST2 & ST3 & ST4 & ST5 & LB1 & LB2 & LB3 & LB4 & LB5 & LB6 & LB7 \\
\hline Acetic acid & 0.445 & 0.698 & 0.554 & 0.815 & 0.376 & 0.436 & 0.593 & 0.251 & 1.776 & 0.169 & 0.417 & 0.113 \\
\hline Butyric acid & 0.219 & 0.312 & 0.128 & 0.481 & 0.358 & 0.215 & 0.301 & 1.510 & 2.905 & 0.059 & 0.148 & 0.311 \\
\hline Hexanoic acid & 0.924 & 1.229 & 0.889 & 0.866 & 1.011 & 0.393 & 0.967 & 0.619 & 2.247 & 0.212 & 0.426 & 0.121 \\
\hline Octanoic acid & 1.814 & 2.897 & 0.998 & 0.405 & 0.515 & 0.258 & 0.341 & nd & 2.634 & 0.152 & 2.059 & 0.182 \\
\hline Decanoic acid & 0.889 & 1.577 & 1.028 & 0.231 & 0.161 & 0.105 & 0.192 & 0.242 & 0.712 & 0.068 & 0.078 & 0.128 \\
\hline Nonanoic acid & 0.292 & 0.839 & 0.334 & nd & 0.635 & 0.358 & 0.776 & 0.708 & 0.065 & 0.574 & 0.374 & 0.061 \\
\hline Acetaldehyde & 1.105 & 2.484 & 2.229 & 3.506 & 2.220 & 0.341 & 1.833 & 2.870 & 0.347 & 1.935 & 0.686 & 1.920 \\
\hline Diacetyl & nd & nd & 0.419 & 0.682 & 0.072 & 0.486 & 1.314 & 0.707 & 0.175 & 0.068 & 0.107 & nd \\
\hline Acetoin & 0.732 & 0.872 & 0.122 & 0.540 & 2.821 & 0.222 & 0.584 & 0.503 & 0.757 & 0.604 & 0.247 & 0.765 \\
\hline 4-Octanone & 0.210 & 0.193 & 0.187 & 0.670 & 0.685 & 0.329 & 1.205 & 0.160 & nd & nd & nd & 0.251 \\
\hline 3-Pentanol & 0.852 & 0.535 & 0.087 & nd & 0.098 & 0.789 & 0.146 & 0.463 & 0.405 & 0.475 & 0.087 & nd \\
\hline 2-Butanone-3-methyl & 0.410 & 0.297 & 0.455 & 0.620 & 0.653 & 0.107 & 0.119 & nd & nd & nd & 0.133 & nd \\
\hline
\end{tabular}

nd: not determined

\subsection{Volatile compounds of yogurt samples made by single strains}

The major volatile compounds of yogurt samples made by single strains of Str. thermophilus and Lb. bulgaricus are presented in Table 4. Carboxylic acids and ketones showed high relative abundance in yogurt samples. Among the carboxylic acid compounds, octanoic, hexanoic and decanoic acids were the most abundant acids in both yogurt groups. Especially, octanoic acid which is responsible for sweat cheesy flavor was produced at high quantities by some strains (i.e., ST1, ST2, ST3, LB4 and LB6). Yogurts made by isolates ST2 and ST3 contained higher amount of decanoic acid which is responsible for rancid flavor. Acetaldehyde is the major aroma compound of yogurt and is produced during 
the fermentation process of milk at far greater quantities than any other volatile compounds [22]. With the exception of the isolates LB1, LB4 and LB6, the rest of the strains produced acetaldehyde at higher quantities (between 1.105 and $3.506 \mathrm{mg} / \mathrm{kg}$ ). Major ketones in the yogurt samples were acetoin, diacetyl, 4-octanone and 2-butanone-3-methyl. Acetoin (2-butanone-3-hydroxy) contributes to the characteristic flavor of yogurt together with acetaldehyde, acetone and diacetyl, and the isolate ST5 was found to be potent acetoin producers. Diacetyl (2,3-butanedione), which is mainly responsible for the buttery flavor in foods, was more abundant in yogurts made by isolate LB2. The relatively higher abundance of carboxylic acids and ketones in single strain yogurts were reported by Dan et al. [23] who screened $17 \mathrm{Lb}$. bulgaricus strains isolated from local fermented cow or yak milk products for volatile compounds profiles.

\subsection{Properties of yogurts made by combined cultures}

It has long been known that yogurt bacteria have a weak ability to grow and produce lactic acid when used alone in yogurt than their ability to grow and develop acidity when used in combination [24]. Combined cultures also contribute to the aroma and texture of yogurt in a positive manner. Selection of strains for a culture combination is of critical importance for commercial applications. Among the selection criteria of single strains for a culture combination are fast acidification during fermentation and slow acidification during cold-storage, development of a texture and balanced flavor, resistance against bacteriophages and more importantly reproducibility. In some cases, when a single strain finds a proper partner strain, their combined action in yogurt is far better than what they do as a single strain. From this fact, in the present work, all the single isolates of Str. thermophilus and Lb. bulgaricus were combined with each other and used in the manufacture of yogurt. The combinations that were able to reduce milk $\mathrm{pH}$ to 4.6 in $\leq 500$ min were taken into further analyses and the rest of the combinations were eliminated.

Table 5. Acidity profiles of experimental yogurts made by combined isolates $(n=3)$

\begin{tabular}{|c|c|c|c|c|c|c|}
\hline \multicolumn{2}{|c|}{ Combinations } & \multirow{2}{*}{$\begin{array}{l}\text { Fermentation time } \\
(\text { min) }\end{array}$} & \multicolumn{2}{|c|}{$\overline{\mathrm{pH}}$} & \multicolumn{2}{|c|}{ Lactic acid (\%) } \\
\hline Str. thermophilus & $\overline{\text { Lb. bulgaricus }}$ & & Day 1 & $\overline{\text { Day } 14}$ & Day 1 & Day 14 \\
\hline \multirow[t]{2}{*}{ ST1 } & LB3 & $500 \pm 23.0^{\mathrm{a}}$ & $4.53 \pm 0.015^{\mathrm{aA}}$ & $4.34 \pm 0.005^{\mathrm{aB}}$ & $0.710 \pm 0.015^{\mathrm{aA}}$ & $0.760 \pm 0.033^{\mathrm{aB}}$ \\
\hline & LB5 & $255 \pm 15.0^{\mathrm{b}}$ & $4.24 \pm 0.013^{\mathrm{bA}}$ & $3.79 \pm 0.020^{\mathrm{bB}}$ & $0.830 \pm 0.005^{\mathrm{bA}}$ & $1.220 \pm 0.004^{\mathrm{bhB}}$ \\
\hline ST2 & LB5 & $500 \pm 2.5^{\mathrm{a}}$ & $4.34 \pm 0.015^{\mathrm{ctiA}}$ & $4.19 \pm 0.030^{\mathrm{cB}}$ & $0.668 \pm 0.001^{\mathrm{cA}}$ & $0.887 \pm 0.013^{\mathrm{cB}}$ \\
\hline ST3 & LB5 & $300 \pm 14.0^{\mathrm{cg}}$ & $4.08 \pm 0.004^{\mathrm{dA}}$ & $3.93 \pm 0.003^{\mathrm{dB}}$ & $0.960 \pm 0.010^{\mathrm{dA}}$ & $1.030 \pm 0.020^{\mathrm{dB}}$ \\
\hline \multirow[t]{7}{*}{ ST4 } & LB1 & $307 \pm 7.5^{\mathrm{c}}$ & $4.31 \pm 0.020^{\mathrm{cA}}$ & $4.20 \pm 0.020^{\mathrm{ceB}}$ & $0.730 \pm 0.030^{\mathrm{aA}}$ & $0.775 \pm 0.005^{\mathrm{aB}}$ \\
\hline & LB2 & $322 \pm 2.5^{\mathrm{de}}$ & $4.23 \pm 0.025^{\mathrm{bA}}$ & $4.17 \pm 0.035^{\mathrm{cB}}$ & $0.820 \pm 0.050^{\mathrm{bA}}$ & $0.920 \pm 0.030^{\mathrm{eB}}$ \\
\hline & LB3 & $327 \pm 7.5^{\mathrm{e}}$ & $4.29 \pm 0.025^{\mathrm{cA}}$ & $4.22 \pm 0.010^{\mathrm{eB}}$ & $0.820 \pm 0.030^{\mathrm{bA}}$ & $0.920 \pm 0.020^{\mathrm{eB}}$ \\
\hline & LB4 & $312 \pm 12.5^{\mathrm{de}}$ & $4.38 \pm 0.020^{\mathrm{fA}}$ & $4.34 \pm 0.015^{\mathrm{aA}}$ & $0.770 \pm 0.030^{\mathrm{ehA}}$ & $0.920 \pm 0.010^{\mathrm{eB}}$ \\
\hline & LB5 & $320 \pm 15.0^{\mathrm{de}}$ & $4.25 \pm 0.065^{\mathrm{bA}}$ & $4.09 \pm 0.015^{\mathrm{fB}}$ & $0.885 \pm 0.075^{\mathrm{fA}}$ & $0.965 \pm 0.065^{\mathrm{eA}}$ \\
\hline & LB6 & $375 \pm 15.0^{\mathrm{f}}$ & $4.44 \pm 0.065^{\mathrm{gA}}$ & $4.28 \pm 0.055^{\mathrm{gB}}$ & $0.710 \pm 0.070^{\mathrm{aA}}$ & $0.820 \pm 0.030^{\mathrm{fB}}$ \\
\hline & LB7 & $372 \pm 12.5^{\mathrm{f}}$ & $4.41 \pm 0.040^{\mathrm{gA}}$ & $4.24 \pm 0.015^{\mathrm{egB}}$ & $0.815 \pm 0.045^{\mathrm{bA}}$ & $0.915 \pm 0.045^{\mathrm{eB}}$ \\
\hline \multirow[t]{7}{*}{ ST5 } & LB1 & $355 \pm 10.0^{\mathrm{f}}$ & $4.35 \pm 0.010^{\text {cfiA }}$ & $4.16 \pm 0.006^{\mathrm{cB}}$ & $0.705 \pm 0.015^{\mathrm{aA}}$ & $0.805 \pm 0.025^{\mathrm{fB}}$ \\
\hline & LB2 & $315 \pm 15.0^{\mathrm{de}}$ & $4.37 \pm 0.015^{1 \mathrm{~A}}$ & $4.03 \pm 0.010^{\mathrm{iB}}$ & $0.750 \pm 0.020^{\mathrm{eA}}$ & $0.830 \pm 0.020^{\mathrm{fB}}$ \\
\hline & LB3 & $287 \pm 2.5^{\mathrm{gh}}$ & $4.44 \pm 0.020^{\mathrm{gA}}$ & $4.26 \pm 0.010^{\mathrm{gB}}$ & $0.770 \pm 0.030^{\mathrm{ehA}}$ & $0.820 \pm 0.000^{\mathrm{fB}}$ \\
\hline & LB4 & $305 \pm 5.0^{\mathrm{c}}$ & $4.29 \pm 0.005^{\mathrm{cA}}$ & $4.10 \pm 0.015^{\mathrm{fB}}$ & $0.780 \pm 0.010^{\mathrm{ehA}}$ & $0.915 \pm 0.045^{\mathrm{eB}}$ \\
\hline & LB5 & $270 \pm 25.0^{\mathrm{gh}}$ & $4.42 \pm 0.015^{\mathrm{gA}}$ & $4.28 \pm 0.015^{\mathrm{gB}}$ & $0.795 \pm 0.015^{\mathrm{hA}}$ & $0.810 \pm 0.010^{\mathrm{fA}}$ \\
\hline & LB6 & $265 \pm 20.0^{\mathrm{h}}$ & $4.52 \pm 0.015^{\mathrm{aA}}$ & $4.29 \pm 0.055^{\mathrm{gB}}$ & $0.790 \pm 0.010^{\mathrm{hA}}$ & $0.815 \pm 0.045^{\mathrm{fA}}$ \\
\hline & LB7 & $275 \pm 25.0^{\mathrm{gh}}$ & $4.51 \pm 0.000^{\mathrm{aA}}$ & $4.32 \pm 0.015^{\mathrm{aB}}$ & $0.765 \pm 0.005^{\mathrm{eh} \mathrm{A}}$ & $0.765 \pm 0.005^{\mathrm{aA}}$ \\
\hline
\end{tabular}

*Different lower case superscript letters in the same columns and upper case superscript letters in the same line indicate statistically different groups $(\mathrm{p}$ $<0.05$ ) 
Table 6. Descriptive sensory evaluation of 14-day old experimental yogurts $(n=3)$

\begin{tabular}{|c|c|c|c|c|c|c|c|}
\hline \multicolumn{2}{|c|}{ Combinations } & \multicolumn{6}{|c|}{ Sensory characteristics } \\
\hline $\begin{array}{c}\text { Str. } \\
\text { thermophilus }\end{array}$ & $\begin{array}{l}\text { Lb. } \\
\text { bulgaricus }\end{array}$ & Odor & Flavor & Texture & Aftertaste & $\begin{array}{c}\text { Overall } \\
\text { flavor effect }\end{array}$ & Remarks \\
\hline \multirow[t]{2}{*}{ ST1 } & LB3 & $\begin{array}{c}\text { Foreign (14) } \\
\text { Acetaldehyde (2) }\end{array}$ & Sour (8) & Firm (10) & Yogurt (14) & Atypical (13) & $\begin{array}{l}\text { Dominant sourness, } \\
\text { bad odor development } \\
\text { after } 14 \text { days of storage }\end{array}$ \\
\hline & LB5 & $\begin{array}{c}\text { Foreign (8) } \\
\text { Acetaldehyde (4) }\end{array}$ & Sour (14) & Firm (8), & Yogurt (14) & Atypical (14) & $\begin{array}{c}\text { Dominant sourness, bad } \\
\text { odor development after } 14 \\
\text { days of storage }\end{array}$ \\
\hline ST2 & LB5 & $\begin{array}{l}\text { Cream-like (5), } \\
\text { Acetaldehyde (4) }\end{array}$ & $\begin{array}{c}\text { Sour (5), } \\
\text { Creamy (4) }\end{array}$ & Firm (12) & Yogurt (14) & $\begin{array}{c}\text { Balanced } \\
\text { yogurt (12) }\end{array}$ & $\begin{array}{l}\text { Suitable for commercial } \\
\text { sour yogurt productions }\end{array}$ \\
\hline ST3 & LB5 & $\begin{array}{c}\text { Foreign (15) } \\
\text { Acetaldehyde (4) }\end{array}$ & Foreign (15) & $\begin{array}{c}\text { Weak body (6), } \\
\text { Whey-off } \\
\text { visible }\end{array}$ & $\begin{array}{c}\text { Yogurt with } \\
\text { dominant sourness } \\
(15)\end{array}$ & $\begin{array}{l}\text { Weak (14), } \\
\text { Foreign (15) }\end{array}$ & $\begin{array}{l}\text { Extremely acidic, not } \\
\text { suitable for commercial } \\
\text { productions }\end{array}$ \\
\hline \multirow[t]{7}{*}{ ST4 } & LB1 & Acetaldehyde (14) & $\begin{array}{c}\text { Sour (7) } \\
\text { Yogurt-like (13) }\end{array}$ & Firm (11) & $\begin{array}{l}\text { Yogurt with } \\
\text { sourness (12) }\end{array}$ & $\begin{array}{c}\text { Balanced } \\
\text { yogurt (14) }\end{array}$ & $\begin{array}{l}\text { Suitable for commercial } \\
\text { sour yogurt productions }\end{array}$ \\
\hline & LB2 & $\begin{array}{c}\text { Foreign (15) } \\
\text { Acetaldehyde (3) }\end{array}$ & $\begin{array}{c}\text { Sour (13), } \\
\text { Yogurt-like (11) }\end{array}$ & Firm (10) & $\begin{array}{l}\text { Yogurt with } \\
\text { sourness (13) }\end{array}$ & Atypical (12) & $\begin{array}{l}\text { Very weak commercial } \\
\text { potential due to } \\
\text { foreign odor }\end{array}$ \\
\hline & LB3 & Acetaldehyde (8) & $\begin{array}{c}\text { Sour (12) } \\
\text { Yogurt-like (8) }\end{array}$ & Firm (13) & $\begin{array}{l}\text { Yogurt with } \\
\text { sourness (14) }\end{array}$ & $\begin{array}{c}\text { Weak } \\
\text { yogurt (13) }\end{array}$ & $\begin{array}{l}\text { Very weak commercial } \\
\text { potential due to } \\
\text { dominant sourness }\end{array}$ \\
\hline & LB4 & Acetaldehyde (12) & $\begin{array}{l}\text { Sour (5) } \\
\text { Yogurt-like (12) } \\
\text { Bitter (7) }\end{array}$ & Firm (11) & $\begin{array}{l}\text { Slight bitterness } \\
\text { (12) }\end{array}$ & $\begin{array}{c}\text { Balanced } \\
\text { yogurt (12) }\end{array}$ & $\begin{array}{l}\text { Slight quality loss during } \\
\text { cold storage, weak } \\
\text { commercial potential }\end{array}$ \\
\hline & LB5 & Acetaldehyde (10) & $\begin{array}{c}\text { Sour (8) } \\
\text { Yogurt-like (10) } \\
\text { Bitter (5) }\end{array}$ & Firm (10) & $\begin{array}{l}\text { Yogurt with } \\
\text { sourness }(8)\end{array}$ & $\begin{array}{c}\text { Balanced } \\
\text { yogurt (12) }\end{array}$ & $\begin{array}{l}\text { Weak commercial potential } \\
\text { due to foreign odor }\end{array}$ \\
\hline & LB6 & Acetaldehyde (10) & $\begin{array}{l}\text { Yogurt (10) } \\
\text { Bitter (8) }\end{array}$ & Firm (12) & Yogurt (14) & $\begin{array}{c}\text { Balanced } \\
\text { yogurt (14) }\end{array}$ & $\begin{array}{c}\text { Weak commercial potential } \\
\text { due to bitterness }\end{array}$ \\
\hline & LB7 & Acetaldehyde (10) & $\begin{array}{c}\text { Sour (10) } \\
\text { Yogurt-like (12), } \\
\text { Creamy (10) }\end{array}$ & Firm (11) & Creamy yogurt (10) & $\begin{array}{c}\text { Balanced } \\
\text { yogurt (13) }\end{array}$ & $\begin{array}{l}\text { Weak commercial potential } \\
\text { due to dominant } \\
\text { creamy taste }\end{array}$ \\
\hline \multirow[t]{7}{*}{ ST5 } & LB1 & Acetaldehyde (10) & $\begin{array}{c}\text { Sour (4) } \\
\text { Yogurt-like (12) }\end{array}$ & Firm (10) & Yogurt (12) & $\begin{array}{c}\text { Balanced } \\
\text { yogurt (14) }\end{array}$ & $\begin{array}{l}\text { Very suitable for } \\
\text { commercial yogurt } \\
\text { production }\end{array}$ \\
\hline & LB2 & Acetaldehyde (13) & $\begin{array}{c}\text { Sour (7) } \\
\text { Yogurt-like (10) } \\
\text { Creamy (13) }\end{array}$ & Firm (10) & Yogurt (12) & $\begin{array}{c}\text { Balanced } \\
\text { yogurt (14) }\end{array}$ & $\begin{array}{l}\text { Very suitable for } \\
\text { commercial yogurt } \\
\text { production }\end{array}$ \\
\hline & LB3 & Acetaldehyde (12) & $\begin{array}{c}\text { Sour (6) } \\
\text { Yogurt-like (10) } \\
\text { Nutty (5) }\end{array}$ & Firm (12) & $\begin{array}{c}\text { Yogurt with } \\
\text { slight sourness (14) }\end{array}$ & $\begin{array}{c}\text { Balanced } \\
\text { yogurt (15) }\end{array}$ & $\begin{array}{l}\text { Very suitable for } \\
\text { commercial yogurt } \\
\text { production }\end{array}$ \\
\hline & LB4 & Acetaldehyde (12) & $\begin{array}{c}\text { Sour (7) } \\
\text { Yogurt-like (13) }\end{array}$ & Firm (11) & $\begin{array}{c}\text { Yogurt with } \\
\text { slight sourness (12) }\end{array}$ & $\begin{array}{c}\text { Balanced } \\
\text { yogurt (13) }\end{array}$ & $\begin{array}{l}\text { Very suitable for } \\
\text { commercial yogurt } \\
\text { production }\end{array}$ \\
\hline & LB5 & Acetaldehyde (13) & $\begin{array}{c}\text { Sour (4), } \\
\text { Yogurt-like (13) }\end{array}$ & Firm (13) & $\begin{array}{c}\text { Yogurt with } \\
\text { slight sourness (13) }\end{array}$ & $\begin{array}{c}\text { Balanced } \\
\text { yogurt (14) }\end{array}$ & $\begin{array}{l}\text { Very suitable for } \\
\text { commercial yogurt } \\
\text { production }\end{array}$ \\
\hline & LB6 & Acetaldehyde (10) & $\begin{array}{c}\text { Sour (5) } \\
\text { Yogurt-like (12) }\end{array}$ & Firm (12) & $\begin{array}{c}\text { Yogurt with } \\
\text { slight sourness (14) }\end{array}$ & $\begin{array}{c}\text { Balanced } \\
\text { yogurt (13) }\end{array}$ & $\begin{array}{c}\text { Very suitable for } \\
\text { commercial yogurt } \\
\text { production }\end{array}$ \\
\hline & LB7 & Acetaldehyde (8) & $\begin{array}{l}\text { Sour (8) } \\
\text { Yogurt-like (5) } \\
\text { Fruity (8) }\end{array}$ & Firm (11) & $\begin{array}{c}\text { Yogurt with } \\
\text { slight sourness (8) }\end{array}$ & $\begin{array}{c}\text { Balanced } \\
\text { yogurt (10) }\end{array}$ & $\begin{array}{l}\text { Suitable for commercial } \\
\text { yogurt production }\end{array}$ \\
\hline
\end{tabular}

*Numbers in brackets represent the average scores for each attribute (0: absent, 1: noticeable, 2.5: very light, 5: light, 7.5: light-medium; 10: medium, 12.5: medium-strong, 15: strong) 
The fermentation time and variations in $\mathrm{pH}$ and percentage of lactic acid values of the combinations are given in Table 5. Fermentation end point was decided as 4.6 and the shortest fermentation time was noted in the combination of ST1/LB5 with $255 \mathrm{~min}$. Except for the combinations of ST1/LB3 and ST2/LB5, all combinations reached to $\mathrm{pH} 4.6$ within reasonable time period. Yogurt samples were stored at $4^{\circ} \mathrm{C}$ for 14 days and in all combinations, the $\mathrm{pH}$ values reduced during cold storage. In some combinations, the reduction in $\mathrm{pH}$ values was very sharp which is not desirable for commercial yogurt production. Overall, combinations of Str. thermophilus ST5 with all Lb. bulgaricus strains developed acidity at moderate levels and these combinations were evaluated as promising for commercial applications. The variation trend of lactic acid values of the yogurt samples were in line with the $\mathrm{pH}$ values.

Undoubtedly, fermentation kinetics of yogurt starter culture is the primary selection criteria of strain combinations. In industrial yogurt productions, yogurt cultures are expected to drop milk pH to $c a$. 4.6 within $4-5 \mathrm{~h}$, since yogurt production lines and daily shifts in yogurt factories are organized based on this figure. Therefore, any combinations created with the commercial production claim must meet this pre-requirement. Fermentation kinetics is important but not the sole criteria for starter culture selection. Yogurts produced by any combinations of yogurt bacteria should be organoleptically acceptable as well. The yogurt samples produced by using combined isolates were subjected to descriptive sensory analysis at day 14 (Table 6). A foreign odor in the combinations of ST1/LB3, ST1/LB5, ST2/LB5, ST3/LB5 and ST4/LB2 were noted by the panelists. In the rest of the samples, a characteristic acetaldehyde odor was dominant. Sourness was the dominant flavor characteristic in almost all combinations, being more pronounced in the combinations of ST1/LB5 and ST4/LB2. A dominant lemon-like sourness was noted in the combination of S19/ML4-1. In only three combinations (ST4 with LB4, LB5 and LB6) a bitterness was noted. No slimy body was reported for the samples. In one sample (ST3/LB5), a time-dependent wheying off was reported and the rest of the samples were found to be physically stable during cold storage.

\section{Conclusion}

In total, 5 Str. thermophilus and $7 \mathrm{Lb}$. bulgaricus strains were screened for their growth patterns and technological performances as single cultures, or for their suitability for yogurt-making as combined cultures. Some combinations showed very poor fermentation performances and these combinations were excluded from the study. Some combinations acidified the milk and reached the target $\mathrm{pH}(4.6 \mathrm{pH})$ within reasonable time period but these combinations were found to be unsuitable for yogurt production by the sensory test panel. Overall, the panel group stressed that combinations of ST5 with all Lactobacillus bulgaricus isolates may have potentials to commercialize. These combinations were also found to be suitable for yogurt-making based on their acidification performances. Future studies will focus on in-depth characterization of yogurts made by these selected combinations.

\section{Author contribution}

Dr. Irem Uzunsoy carried out growth pattern analysis, and microbiological studies. Dr. Sebnem Ozturkoglu Budak run volatile compounds analysis. Dr. Tuba Sanli coordinated sensory analysis. Dr. Birce Taban undertook microbiological studies. Prof. Dr. Aykut Aytaç, Prof. Dr. Nuray Yazıhan and Prof. Dr. Barbaros Ozer were responsible for the conceptualization, management of the project, running microbiological and textural analysis, statistical evaluations and writing the paper.

\section{Acknowledgement}

This study was financially supported jointly by The Scientific and Technical Research Council of Turkey (Project No: 112D052) and FARMAPARK R\&D Biotechnology, Machinery, Chemistry, Food LC (Konya, Turkey). 


\section{Conflict of interest}

The authors declare that there are no conflicts of interest.

\section{References}

[1] Kosikowski FV, Mistry VV. Cheese and Fermented Milk Foods. Volume 1: origins and principles. 3rd edition. Westport: F. V. Kosikowski LLC; 1997.

[2] Fisberg M, Machado R. History of yogurt and current patterns of consumption. Nutrition Reviews. 2015; 73(Supplement 1): 4-7.

[3] Aryana KJ, Olson DW. A 100-year review: Yogurt and other cultured dairy products. Journal of Dairy Science. 2017; 100: 9987-10013.

[4] Codex Alimentarius. Codex Standard for Fermented Milks. Codex Stand 243-2003. FAO. 2003.

[5] Xanthopoulos V, Petridis D, Tzanetakis N. Characterization and classification of Streptococcus thermophilus and Lactobacillus delbrueckii subsp. bulgaricus strains isolated from traditional Greek yogurts. Journal of Food Science. 2001; 66: 747-752.

[6] Pourahmad R, Assadi MM. Use of isolated autochthonous starter cultures in yogurt production. International Journal of Dairy Technology. 2007; 60: 259-262.

[7] Özer B. Yogurt Science and Technology. Izmir: Sidas Publishing; 2006.

[8] Huang YN, You CP, Liu ZM. Cloning of D-lactate dehydrogenase genes of Lactobacillus delbrueckii subsp bulgaricus and their roles in D-lactic acid production. Biotechnology. 2017; 7: Article No. 194.

[9] Li C, Sun W, Zhang GF, Liu LB. Effect of the absence of the CcpA gene on growth, metabolic production, and stress tolerance in Lactobacillus delbrueckii ssp. bulgaricus. Journal of Dairy Science. 2016; 99: 104-111.

[10] Yerlikaya O, Akpinar A, Kilic S. Physicochemical, microbiological, rheological and sensory properties of set-type yogurt produced with two different origins: wild Lactobacillus delbrueckii subsp bulgaricus and Streptococcus thermophilus strains. Italian Journal of Food Science. 2013; 25: 412-420.

[11] Baruzzi F, Quitieri L, Caputo L, Cocconcelli P, Borcakli M, Owczarek L, Jasińska UT, Skąpska S, Morea M. Improvement of Ayran quality by the selection of autochthonous microbial cultures. Food Microbiology. 2011; 60: 92-103.

[12] Ispirli H, Dertli E. Isolation and identification of exopolysaccharide producer lactic acid bacteria from Turkish yogurt. Journal of Food Processing and Preservation. 2017; e-13351.

[13] Yazihan N, Özer B. Technology and health claim evaluation of probiotic dairy products. Chapter 5. In: El Enshasy, H, Yang S T. (eds) Probiotics, the natural microbiota in living organisms: Fundamentals and Applications. USA: CRC Press; 2021.

[14] Dimov S, Kirilov N, Peykov S, Ivanova I. Growth characteristics of twenty Lactobacillus delbrueckii strains isolated from Bulgarian home-made yoghurts. Biotechnol Biotechnological Equipment. 2007; 21: 172-176.

[15] Lee JH, Diono R, Kim GY, Min D. Optimization of solid phase microextraction analysis for the headspace volatile compounds of Parmesan cheese. Journal of Agriculture and Food Chemistry. 2003; 51: 1136-1140.

[16] Meilgaard M, Civille GV, Carr B. Sensory evaluation techniques. Boca Raton: CRC Press; 1999.

[17] Hourichi H, Sasaki Y. Effect of oxygen on symbiosis between Lactobacillus bulgaricus and Streptococcus thermophilus. Journal of Dairy Science. 2012; 95: 2904-2909.

[18] Sasaki Y, Hourichi H, Kawashima H, Mukai T. NADH oxidase of Streptococcus thermophilus 1131 is required for the effective yogurt fermentation with Lactobacillus delbrueckii subsp. bulgaricus 2038. Bioscience of Microbiota, Food and Health. 2014; 33: 31-40.

[19] Lourens-Hattingh A, Viljoen BC. Yogurt as a probiotic carrier. International Dairy Journal. 2001; 1: 1-17.

[20] Özer B, Bell AE, Grandison AS, Robinson RK. Rheological properties of concentrated yoghurt (labneh). Journal of Texture Studies. 1998; 29: 67-79.

[21] Ciron CJE, Gee VL, Kelly AL, Auty MAE. Comparison of the effects of high-pressure microfluidization and conventional homogenization of milk on particle size, water retention and texture of non-fat and low-fat yoghurts. International Dairy Journal. 2010; 20: 314-320.

[22] Marshall VM, Cole WM. Threonine aldolase and alcohol dehydrogenase activities in Lactobacillus bulgaricus and Lactobacillus acidophilus and their contribution to flavour production in fermented milks. Journal of Dairy Research. 1983; 50: 375-379. 
[23] Dan T, Ren W, Liu Y, Tian J, Chen H, Li T, Liu W. Volatile flavor compounds profile and fermentation characteristics of milk fermented by Lactobacillus delbrueckii subsp. bulgaricus. Frontiers in Microbiology. 2019; 10: Article No. 2183.

[24] Wang T, Xu Z, Lu S, Xin M, Kong J. Effect of glutathione on acid resistance and symbiosis between Streptococcus thermophilus and Lactobacillus delbrueckii subsp. bulgaricus. International Dairy Journal. 2016; 61: 22-28. 